\title{
Pengendalian Risiko Kecelakaan dalam Penerapan International Safety Management Code di Kapal Tanker
}

\author{
Sugiyanto ${ }^{1}$, Herwin Nasution $^{2}$, Nur Oktriani Levana ${ }^{3}$ \\ 1, 2, 3 Prodi Ketatalaksanaan Angkutan Laut dan Kepelabuhanan \\ Sekolah Tinggi Ilmu Pelayaran, Jakarta \\ Jl. Marunda Makmur No. 1 Cilincing, Jakarta Utara. Jakarta 14150
}

\begin{abstract}
Abstrak
Keselamatan merupakan isu utama yang harus menjadi perhatian bersama oleh semua stake holder transportasi perairan, terutama oleh pemerintah, asosiasi pelayaran, dan pengusaha pemilik kapal. Masalah yang dikaji dalam penelitian ini adalah identifikasi risiko kecelakaan di kapal tanker dan bagaimana pengendalian risiko kecelakaan kapal tersebut. Tujuan penelitian ini yaitu untuk mengetahui identifikasi risiko kecelakaan kapal tanker dan mengetahui pengendalian risiko kecelakaan kapal dalam penerapan International Safety Management Code di kapal tanker. Metode pendekatan yang digunakan adalah kuantitatif dengan analisa data menggunakan manajemen resiko. Dari hasil penelitian diperoleh kesimpulan bahwa resiko yang teridentifikasi dari kegiatan yang berlangsung selama berlayarnya kapal meliputi kapal kandas, kapal menabrak dermaga, kapal menabrak kapal lain, kebakaran, ledakan, limbah buangan dari got kapal, muatan tumpah, tersengat arus listrik saat penyambungan arus, crew jatuh ke laut, crew terjatuh dari tangga, tali lempar mengenai crew di dermaga, crew terlilit tali kapal, crew sakit, crew tergelincir di tangga monyet. Perusahaan pelayaran harus menerapkan ISM Code dengan melaksanakan beberapa elemen ISM Code untuk mengurangi angka kecelakaan diatas kapal, yaitu elemen 2 (dua) kebijakan mengenai keselamatan dan perlindungan lingkungan, elemen 4 (empat) Orang yang ditunjuk sebagai koordinator/penghubung antara pimpinan perusahaan dan kapal (DPA-Designated Person Ashore), elemen 5 (lima) Tanggung jawab dan wewenang Nakhoda / Master, elemen 7 (tujuh) pengembangan program untuk keperluan operasi-operasi kapal, elemen 8 (delapan) kesiapan terhadap keadaan darurat.
\end{abstract}

Copyright $\odot$ 2020, Prosiding Seminar Pelayaran dan Riset Terapan

Kata Kunci: pengendalian, kecelakaan, safety management

Permalink/ DOI : https://doi.org/10.36101/pcsa.v2i1.127

\section{PENDAHULAN}

Negara Indonesia sebagai negara kepulauan yang terdiri dari ribuan pulau, tentunya sangat mengandalkan transportasi laut sebagai salah satu sarana untuk memudahkan masyarakat dalam melakukan perjalanan antar pulau.

Transportasi laut merupakan angkutan massal penting yang tidak bisa dilakukan oleh jenis transportasi lain. Baik untuk keperluan angkutan orang maupun barang, jenis transportasi in mampu mengangkut hingga ribuan penumpang dan ratusam ribuan metric ton kargo. Semakin penting bagi Indonesia yang merupakan Negara kepulauan terbesar dunia untuk pemerataan ekonomi dan pengembangan social budaya nusantara.

Angkutan transportasi laut merupakan moda transportasi yang sarat akan regulasi (aturan). Sejak kapal dipesan untuk dibangun hingga kapal beroperasi, selalu ada peraturan yang harus dipatuhi dan di dalam proses pelaksanaannya pun selalu dilakukan pengawasan. Hal tersebut dilakukan sebagai upaya mewujudkan keadaan terpenuhinya persyaratan keselamatan dan keamanan yang menyangkut angkutan di perairan. Namun transportasi laut di Indonesia saat ini bisa dikatakan sedang mengalami masalah. Kecelakaan laut yang menelan banyak korban jiwa dan harta benda terjadi bergantian. Akar penyebab kecelakaan laut belum ditangani secara serius sehingga bahaya selalu mengintai pengguna jasa angkutan laut setiap saat.

Namun kenyataannya masih banyak terjadi kecelakaan kapal. Berdasarkan data kecelakaan yang di investigasi KNKT (2010-2016) diketahui bahwa kecelakaan

kapal yang disebabkan oleh kesalahan manusia (human error) sebesar $\pm 80 \%$ dan dari seluruh kesalahan manusia tersebut diketahui pula 
bahwa sekitar $80 \%$ diantaranya diakibatkan oleh buruknya manajemen (poor management) perusahaan pelayaran (ISM training, 2010). Sistem manajemen perusahaan pelayaran atau operator kapal berpengaruh kuat terhadap keadaan kelaiklautan kapal.

Keselamatan merupakan isu utama yang harus menjadi perhatian bersama oleh semua stake holder transportasi perairan, terutama oleh pemerintah, asosiasi pelayaran (INSA), dan pengusaha pemilik kapal. Keselamatan harus mencakup keselamatan orang, barang dan lingkungan sehingga segala dampak menyangkut ketiga hal tersebut bisa diminimalisir demi kepentingan bersama.

Berdasarkan observasi yang peneliti lakukan di lapangan, ditemukan adanya beberapa faktor penyebab terjadinya risiko kecelakaan. Diantaranya yaitu faktor pengawasan SDM yang masih rendah terhadap penerapan ISM-Code di atas kapal. Dimana pengawasan ini dilakukan dibawah tanggung jawab DPA (Designated Person Ashore) yang merupakan utusan dari perusahaan sebagai penghubung antara pihak darat kepada pihak laut. Kemudian perawatan mesin dan bagian kapal serta rutinitas dock kapal yang tidak sesuai dengan waktu yang ditentukan, dimana telah ditetapkan dalam ISM-Code elemen 10 bahwa kapal dan perlengkapannya harus dipelihara dan diusahakan selalu baik dan berfungsi melalui pengujian secara teratur. Serta faktor lainnya yaitu pembekalan awak kapal terhadap pengendalian risiko atau keadaan darurat di atas kapal yang masih kurang.

International Safety Management Code merupakan produk dari IMO yang akhirnya diadopsi oleh SOLAS pada tahun 1994, dan juga dikonsolidasikan dalam SOLAS convention. ISMCode membentuk suatu standar international untuk manajemen dan operasi kapal yang aman. Standar tersebut dilaksanakan dengan menetapkan aturan bagi perusahaan pelayaran yang berhubungan dengan keselamatan dan pencegahan polusi serta dalam keselamatan operasional kapal dan pencegahan kecelakaan kapal yang bertujuan untuk memastikan keselamatan di laut, mencegah kecelakaan manusia atau hilangnya nyawa atau jiwa, menghindari kerusakan lingkungan yang diakibatkan kecelakaan dan pencemaran di laut, serta menjaga muatan barang yang di angkut dan konstruksi kapal.

PT. Samudera Energi Tangguh merupakan salah satu perusahaan pelayaran spesialis kapal Tanker di Indonesia yang berkembang pesat dalam menyediakan pelayaran atau armada yang laik laut. Untuk itu diperlukan adanya dukungan dari perusahaan atas kebutuhan operasional kapal yang aman, perlindungan terhadap lingkungan, dan manajemen perusahaan yang baik dengan mengoptimalkan penerapan International Safety Management Code. Maka PT. Samudera Energi Tangguh menerapkan sistem keselamatan yang sesuai dengan International Safety Management Code sehingga dengan berjalannya penerapan sistem tersebut secara efektif dapat mengurangi risiko kecelakaaan kapal di laut.

Namun dalam penerapan International Safety Management Code PT. Samudera Energi Tangguh yang telah tersertifikasi masih memiliki tingkat risiko kecelakaan yang belum bisa dikendalikan secara efektif dalam penerapan International Safety Management Code di atas kapal.

PT. Samudera Energi Tangguh masih belum dapat menjalankan kebijakan keselamatan dan perlindungan ke setiap anak buah kapal sehingga masih mengalami kecelakaan kerja. Maka dari itu perusahaan perlu menerapkan manajemen risiko terhadap penanganan kecelakaan kerja crew kapal. Prosedur keselamatan kerja dan emergency plan dijalankan untuk mengurangi resiko kecelakaan kerja. Controling pelatihan keselamatan kerja diatas kapal sudah menjadi dasar ISM Code. Setiap crew harus mengetahui Basic Safety Training sehingga risiko kecelakaan kerja diatas kapal bias ditekan dan pelaporan setiap kegiatan diatas kapal harus didokumentaskan supaya mengetahui perkembangan situasi diatas kapal dari sisi emergency plan dan lain-lain.

Berdasarkan hal tersebut peneliti menguraikan identifikasi masalah, yaitu:

1. Masih terdapat kecelakaan di atas kapal MT. Sinar Mataram PT. Samudera Energi Tangguh

2. Kurang sesuainya pengendalian risiko kecelakaan kapal MT. Sinar Mataram dengan penerapan International Safety Management Code di PT. Samudera Energi Tangguh pada tahun 2017

3. Kurangnya penerapan International Safety Management Code di atas kapal sehingga masih terdapat risiko kecelakaan kapal..

4. Kurang efektifnya support management darat dalam menindak lanjuti kebutuhan alat pelindung diri bagi crew kapal terhadap pengendalian risiko diatas kapal.

5. Belum efektifnya latihan dan program drill oleh crew yang seharusnya dilakukan secara berkala di atas kapal .

Berdasarkan uraian yang telah disampaikan dalam latar belakang, peneliti merumuskan permasalahan sebagai berikut:

1. Apa saja risiko kecelakaan kapal MT. Sinar Mataram PT. Samudera Eneergi Tangguh? 
2. Bagaimana pengendalian risiko kecelakaan kapal MT. Sinar Mataram dengan penerapan International Safety Management Code di PT. Samudera Energi Tangguh pada tahun 2017 ?

Kemudian tujuan dilaksanakannya penelitian ini yaitu:

1. Mengetahui identifikasi risiko kecelakaan kapal MT. Sinar Mataram di PT. Samudera Energi Tangguh pada tahun 2017.

2. Mengetahui pengendalian risiko kecelakaan kapal dalam penerapan International Safety Management Code di kapal MT. Sinar Mataram PT. Samudera Energi Tangguh pada tahun 2017

\section{METODE}

Adapun metode pendekatan yang dipergunakan dalam penulisan penelitian ini adalah menggunakan metode kualitatif, karena peneliti ingin menggambarkan atau melukiskan fakta-fakta atau keadaan ataupun gejala yang tampak pada setiap kegiatan pelayaran di MT. Sinar Mataram PT. Samudera Energi Tangguh. Kemudian analisa data yang digunakan adalah manajemen resiko.

\section{HASIL DAN PEMBAHASAN}

Pada tanggal 25 Juni 2009, PT. Silikargo Line didirikan yang mana dalam perjalanannya, di pertengahan tahun 2013 telah mengalami perubahan nama menadi PT. Samudera Energi Tangguh. Perusahaan pelayaran nasional in mempunyai kegiatan usaha di bidang industrial shipping maupun mempunyai penunjangnya. Dalam hal ini yaituu penyediaan jasa angkutan laut guna menunjang aktivitas industry kimia curah \& cair, penunjang kegiatan lepas pantai, minyak \& gas, serta keagenan.

PT. Samudera Energi Tangguh secara garis besar memiliki lingkup bisnis sebagai berikut: melayani kepentingan industri minyak di lepas pantai (offshore support servives), oleh karena itu, perusahaan menyediakan layanan pengoperasian kapal-kapal offshore, dimana keamanan serta keselamatan (zero accident), kesehatan kerja, serta kepedulian terhadap aspek lingkungan menjadi kunci utama dari kualitas layanan yang diberikan. Salah satu unit kapal yang dimiliki adalah OB. Sinar handil. Kapal ini di golongkan dalam anti pollution barge.

Sedangkan layanan yang di berikan dalam bidang ini tidak tebatas dalam jasa sewa kapal, namun memiliki ruang lingkup yang lebih luas, termasuk di dalamnya manajemen sistem dalam industri minyak lepas pantai. Sebgai gambaran adalah menerapkan manajemen sistem service terhadap kapal-kapal ASD tug milik BP tangguh.

PT. Samudera Energi Tangguh melakukan investasi dengan membeli satu unit kapal tanker chemical IMO 2/3 yang diberi nama MT. Sinar Mataram. Melanjutkan tren positip dalam upaya pengembangan perusahaan terutama untuk menunjang kegiaan industry offshore support services, PT. Samudera Energi Tangguh menginvestasikan sebagian modal untuk membangun satu unit ant pollution barge, OB. Sinar handil. Dimana kontrak awalnya adalah mensupport kegiatan penanganan pencemaran limbah (unit storage) di salah satu kontraktor kontrak kerja sama migas (KKKS-MIGAS) yang beroperasi di wilayah nusantara, dengan durasi kontrak tiga tahun.

Mengidentifikasi risiko merupakan sebuah metode untuk mengetahui frekuensi dan seberapa besar dampak dari risiko tersebut. Peneliti telah membuat dan menjabarkan beberapa masalah yang terjadi di kapal MT. Sinar Mataram PT. Samudera Energi Tangguh.

Langkah 1. Identifikasi Masalah

Tabel 1. Identifikasi Risiko kapal MT. Sinar Mataram di PT. SET

\begin{tabular}{|c|l|}
\hline No & \multicolumn{1}{|c|}{ Identifikasi Risiko } \\
\hline \hline 1 & Kapal Kandas \\
\hline 2 & Kapal Menabrak Dermaga \\
\hline 3 & Kapal menabrak kapal lain \\
\hline 4 & Kebakaran \\
\hline 5 & Ledakan \\
\hline 6 & Limbah buangan dari air got kapal \\
\hline 7 & Muatan tumpah \\
\hline 8 & $\begin{array}{l}\text { Tersengat arus listrik saat } \\
\text { penyambungan arus }\end{array}$ \\
\hline 9 & Crew terpeleset \\
\hline 10 & Crew jatuh ke laut \\
\hline 11 & Crew terjatuh dari tangga \\
\hline 12 & Tali lempar mengenai Crew di dermaga \\
\hline 13 & Crew Terlilit tali kapal \\
\hline 14 & Crew sakit \\
\hline 15 & Crew tergelincir di tangga monyet \\
\hline
\end{tabular}

Langkah 2. Analisis risiko melibatkan tingkat kemungkinan dan konsekuensi dari suatu risiko. Tabel 2. Tingkat konsekuensi 


\section{http://ejournal.stipjakarta.ac.id/index.php/pcsa}

\begin{tabular}{|c|l|l|}
\hline Tingkat & \multicolumn{1}{|c|}{ Deskripsi } & \multicolumn{1}{c|}{ Penjelasan } \\
\hline 1 & Sangat Rendah & Tidak ada cidera, kerugian materi sangat kecil. \\
\hline 2 & Rendah & $\begin{array}{l}\text { Memerlukan perawatan P3K, kerugian materi } \\
\text { sedang. }\end{array}$ \\
\hline 3 & Sedang & $\begin{array}{l}\text { Memerlukan perawatan medis dan } \\
\text { mengakibatkan hilangnya hari kerja / hilangnya } \\
\text { fungsi anggota tubuh untuk sementara waktu, } \\
\text { kerugian materi cukup besar. }\end{array}$ \\
\hline 4 & Tinggi & $\begin{array}{l}\text { Cidera yang mengakibatkan cacat / hilangnya } \\
\text { fungsi tubuh secara total, tidak berjalannya } \\
\text { proses produksi, kerugian materi besar. }\end{array}$ \\
\hline 5 & Sangat tinggi & $\begin{array}{l}\text { Menyebabkan kematian, kerugian materi sangat } \\
\text { besar. }\end{array}$ \\
\hline
\end{tabular}

Sumber: AS/NZS 4360:1999

Tabel 3. Tingkat Kemungkinan

\begin{tabular}{|c|l|l|}
\hline Tingkat & \multicolumn{1}{|c|}{ Deskripsi } & \multicolumn{1}{|c|}{ Penjelasan } \\
\hline A & Sangat Tinggi & $\begin{array}{l}\text { Suatu kejadian pasti akan terjadi pada } \\
\text { semua kondisi / setiap kegiatan yang } \\
\text { dilakukan. }\end{array}$ \\
\hline B & Tinggi & $\begin{array}{l}\text { Suatu kejadian mungkin akan terjadi pada } \\
\text { semua kondisi. }\end{array}$ \\
\hline C & Sedang & $\begin{array}{l}\text { Suatu kejadian akan terjadi pada beberapa } \\
\text { kondisi tertentu. }\end{array}$ \\
\hline D & Rendah & $\begin{array}{l}\text { Suatu kejadian mungkin terjadi pada } \\
\text { beberapa kondisi tertentu, namun kecil } \\
\text { kemungkinan terjadinya. }\end{array}$ \\
\hline E & Sangat Rendah & $\begin{array}{l}\text { Suatu insiden mungkin dapat terjadi pada suatu } \\
\text { kondisi yang khusus / luar biasa / setelah } \\
\text { bertahun-tahun. }\end{array}$ \\
\hline
\end{tabular}

Tabel 4. Hasil Pemetaan dari beberapa Risiko

\begin{tabular}{|c|c|c|c|c|c|c|}
\hline & & $\begin{array}{c}\text { Sangat } \\
\text { Rendah }\end{array}$ & Rendah & Sedang & Tinggi & Sangat tinggi \\
\hline & & 1 & 2 & 3 & 4 & 5 \\
\hline A & $\begin{array}{l}\text { Sangat } \\
\text { tinggi }\end{array}$ & & & & & \\
\hline B & Tinggi & & & $(14)$ & & \\
\hline C & Sedang & & & $(9),(11)$ & & \\
\hline D & Rendah & & & & $\begin{array}{c}(6),(8),(10), \\
(12),(13),(15)\end{array}$ & $(4)$ \\
\hline E & $\begin{array}{l}\text { Sangat } \\
\text { Rendah }\end{array}$ & \multicolumn{7}{|c|}{ Konsekuensi } & & $\begin{array}{c}(1),(2),(3), \\
(5),(7)\end{array}$ \\
\hline
\end{tabular}

Langkah 3. Evaluasi Risiko

Tabel 5. Evauasi risiko MT. Sinar Mataram

\begin{tabular}{|c|c|c|c|c|}
\hline$\frac{\frac{8}{2}}{\frac{x}{2}}$ & Risiko yang dapat terjadi & $\begin{array}{c}\text { Tingkat } \\
\text { risiko } \\
\text { saat ini }\end{array}$ & $\begin{array}{c}\text { Tingkat } \\
\text { risiko }\end{array}$ & 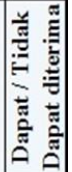 \\
\hline 1 & Kapal Kandas & E5 & Tinggi & TD \\
\hline 2 & Kapal menabrak dermaga & E5 & Tinggi & TD \\
\hline 3 & Kapal menabrak kapal lain & E5 & Tinggi & TD \\
\hline 4 & Kebakaran & D5 & Tinggi & TD \\
\hline 5 & Ledakan & E5 & Tinggi & TD \\
\hline 6 & Limbah buangan dari got kapal & D4 & Tinggi & TD \\
\hline 7 & Muatan tumpah & E5 & Tinggi & TD \\
\hline 8 & Tersengat arus listrik saat penyambungan arus & D4 & Tinggi & TD \\
\hline 9 & Crew terpeleset & $\mathrm{C} 3$ & Sedang & $\mathrm{DD}$ \\
\hline 10 & Crew jatuh ke laut & D4 & Tinggi & TD \\
\hline 11 & Crew terjatuh dari tangga & $\mathrm{C} 3$ & Sedang & $\mathrm{DD}$ \\
\hline 12 & Tali lempar mengenai $c r e w$ di dermaga & D4 & Tinggi & TD \\
\hline 13 & Crew terlilit tali kapal & D4 & Tinggi & TD \\
\hline 14 & Crew Sakit & B3 & Tinggi & TD \\
\hline 15 & Crew tergelincir di tangga monyet & D4 & Tinggi & $\mathrm{TD}$ \\
\hline
\end{tabular}

Berdasarkan data tersebut diatas, maka dapat dilihat bahwa dari sekian banyaknya kegiatan maka akan menghasilkan beberapa risiko di kapal MT. Sinar Mataram, makan peneliti akan menguraikannya sebagai berikut :

a) Kapal kandas

Kapal kandas terjadi gelombang tinggi, kapal menabrak karang. Potensi atau dampak risiko yang dihadapi adalah crew kapal mengalami cidera ringan sampai cidera berat, mengalami kerugian pendapatan, kapal rusak.

Tingkat Risiko saat ini berdasarkan tabel AS/NZS 4360:1999, tingkat kemungkinan berada di Level E (Jarang sekali terjadi), konsekuensinya berada di level 5 (Sangat Tinggi). Sehingga tingkat risiko saat ini kemungkinan sejauh ini tidak pernah terjadi dan bila terjadi maka tingkat keparahannya sangat tinggi serta memerlukan biaya yang besar untuk memperbaiki.

b) Kapal menabrak dermaga

Kapal menabrak dermaga terjadi karena gelombang tinggi, terserat arus yang kuat dan angina yang kencang sehingga kapal kehilangan kendali. Potensi atau dampak risiko yang dihadapi adalah crew kapal mengalami cidera ringan sampai cidera berat, mengalami kerugian pendapatan, kapal dan dermaga rusak.

Tingkat Risiko saat ini berdasarkan tabel AS/NZS 4360:1999, tingkat kemungkinan berada di Level E (Jarang sekali terjadi), konsekuensinya berada di level 5 (Sangat Tinggi). Sehingga tingkat risiko saat ini kemungkinan sejauh ini tidak pernah terjadi dan bila terjadi maka tingkat keparahannya sangat tinggi serta memerlukan biaya yang besar untuk memperbaiki kapal serta membayar ganti rugi kerusakan dermaga yang di tabrak.

c) Kapal menabrak kapal lain

Kapal menabrak kapal lain terjadi karena kesalahan prosedur navigasi, komunikasi tidak terjaga dengan baik. Potensi atau dampak risiko yang dihadapi adalah crew kapal mengalami cidera ringan sampai cidera berat, mengalami kerugian pendapatan, kapal rusak.

Tingkat Risiko berdasarkan tabel AS/NZS 4360:1999, tingkat kemungkinan berada di Level E (Jarang sekali terjadi), konsekuensinya berada di level 5 (Sangat Tinggi). Sehingga tingkat risiko saat ini kemungkinan sejauh ini tidak pernah terjadi dan bila terjadi maka tingkat keparahannya sangat tinggi serta memerlukan biaya yang besar untuk memperbaiki serta membayar ganti keugian kerusakan kapal lain yang di tabrak.

d) Kebakaran

Kebakaran terjadi karena adanya kebocoran bahan bakar minyak, minyak pelumas, dan gas buangan. Potensi atau dampak risiko yang akan dihadapi adalah terjadi ledakan, kehilangan nyawa, kapal 
tidak dapat di gunakan, membayar pengobatan crew yang terluka.

Tingkat Risiko saat ini berdasarkan tabel AS/NZS 4360:1999, tingkat kemungkinan berada di Level D (kecil kemungkinan terjadinya), tingkat akibatnya berada di level 5 (Sangat Tinggi). Sehingga tingkat risiko saat ini kemungkinan sejauh ini pernah terjadi dan bila terjadi maka tingkat keparahannya sangat tinggi.

e) Ledakan

Ledakan terjadi karena adanya kebakaran di salah satu bagian kapal yang kemudian tersambat dengan bahan bakar minyak atau gas. Potensi atau dampak risiko yang akan dihadapi adalah terjadi kehilangan nyawa, kapal tidak dapat di gunakan, perusahaan mendapat kerugian yang besar, membayar pengobatan crew yang terluka.

Tingkat Risiko saat ini berdasarkan tabel AS/NZS 4360:1999, tingkat kemungkinan berada di Level E (jarang sekali terjadi), tingkat akibatnya berada di level 5 (Sangat Tinggi). Sehingga tingkat risiko saat ini kemungkinan sejauh ini tidak pernah terjadi dan bila terjadi maka tingkat keparahannya sangat tinggi.

f) Limbah buangan dari air got kapal

Limbah buangan dari air got kapal terjadi karena kurangnya pemahaman pada setiap crew kapal mengenai prosedur pembuangan limbah. Potensi atau dampak risiko yang dihadapi adalah tercemarnya lingkungan, mengganti kerugian akibat tercemarnya laut.

Tingkat Risiko saat ini berdasarkan tabel AS/NZS 4360:1999, tingkat kemungkinan berada di Level D (kecil kemungkinan terjadi), tingkat akibatnya berada di level 4 (Tinggi). Sehingga tingkat risiko saat ini kemungkinan pernah terjadi dan bila terjadi tingkat keparahannya tinggi.

g) Muatan tumpah

Muatan tumpah terjadi karena pengoperasian saat loading atau discharging yang dimana pada saat itu cuaca sedang buruk kemudian terdapat kebocoran pipa. Potensi atau dampak risiko yang dihadapi adalah pencemaran terhadap lingkungan, mengganti kerugian akibat tercemarnya laut.

Tingkat Risiko saat ini berdasarkan tabel AS/NZS 4360:1999, tingkat kemungkinan berada di Level E (jarang sekali terjadi), tingkat akibatnya berada di level 5 (Sangat tinggi). Sehingga tingkat risiko saat ini kemungkinannya sejauh ini tidak pernah terjadi dan bila terjadi tingkat keparahannya sangat tinggi.

h) Tersengat arus listrik saat penyambungan arus Tersengat arus listrik saat penyambungan arus terjadi karena Crew bekerja sendirian, tidak menggunakan sarung tangan . Potensi atau dampak risiko yang akan dihadapi adalah Cidera ringan sampai cidera berat, membayar biaya pengobatan crew

Tingkat Risiko saat ini berdasarkan tabel AS/NZS 4360:1999, tingkat kemungkinan berada di Level D (Jarang), tingkat akibatnya berada di level 4 (tinggi). Sehingga tingkat risiko saat ini kemungkinan pernah terjadi dan bila terjadi tingkat keparahannya tinggi.

i) Crew terpeleset

Crew terpeleset karena lantai yang licin terkena percikan air laut serta ombak besar. Potensi atau dampak risiko yang akan dihadapi adalah cidera ringan, pengeluuaran biaya untuk pengobatan crew yang cidera.

Tingkat Risiko saat ini berdasarkan tabel AS/NZS 4360:1999, tingkat kemungkinan berada di Level C (pernah terjadi), tingkat akibatnya berada di level 3 (sedang). Sehingga tingkat risiko saat ini kemungkinan pernah terjadi dan bila terjadi tingkat keparahannya sedang.

j) Crew jatuh ke laut

Crew jatuh ke alaut terjadi karena terlilit tali tambat, kurang pemahaman prosedur mooring, cuaca buruk, tergelincir. Potensi atau dampak risiko yang akan dihadapi adalah cidera ringan sampai cidera berat, pengeluuaran biaya untuk pengobatan crew yang cidera.

Tingkat Risiko saat ini berdasarkan tabel AS/NZS 4360:1999, tingkat kemungkinan berada di Level B (kemungkinan terjadi), tingkat akibatnya berada di level 4 (tinggi). Sehingga tingkat risiko saat ini kemungkinan pernah terjadi dan tingkat keparahannya tinggi.

k) Crew terjatuh dari tangga

Crew terjatuh dari tangga terjadi karena tangga licin dan ombak besar. Potensi atau dampak risiko yang akan dihadapi adalah cidera ringan sampai cidera berat, pengeluuaran biaya untuk pengobatan crew yang cidera.

Tingkat Risiko berdasarkan tabel AS/NZS 4360:1999, tingkat kemungkinan berada di Level $\mathrm{C}$ (pernah terjadi), tingkat konsekuensinya berada di level 3 (sedang). Sehingga tingkat risiko saat ini kemungkinan pernah terjadi dan bila terjadi keparahannya sedang.

1) Tali lempar mengenai Crew di area dermaga

Tali lempar mengenai crew di area dermaga terjadi karena kurang nya komunikasi dengan pihak dermaga, crew tidak menyingkir atau menghindar saat tali dilemparkan. Potensi atau dampak risiko yang akan dihadapi adalah cidera ringan sampai cidera berat, pengeluuaran biaya untuk pengobatan crew yang cidera.

Tingkat Risiko saat ini berdasarkan tabel AS/NZS 4360:1999, tingkat kemungkinan berada di Level B (kemungkinan terjadi), tingkat akibatnya berada di level 4 (tinggi). Sehingga tingkat risiko saat ini 
kemungkinan pernah terjadi dan bila terjadi tingkat keparahannya tinggi.

m) Terlilit tali tambat kapal

Terlilit tali tambat terjadi karena crew tidak melakukan komunikasi VHF dengan perira jaga dianjungan, melakukan penmbatan seorang diri. Potensi atau dampak risiko yang akan dihadapi adalah cidera ringan sampai cidera berat, jatuh kelaut hingga kehilangan nyawa, pengeluuaran biaya untuk pengobatan crew yang cidera.

Tingkat Risiko saat ini berdasarkan tabel AS/NZS 4360:1999, tingkat kemungkinan berada di Level D (kecil kemungkinan trjadi), tingkat akibatnya berada di level 4 (tinggi). Sehingga tingkat risiko saat ini kemungkinan pernah terjadi dan bila terjadi tingkat keparahannya tinggi.

Tingkat akibatnya berada di level 4 (tinggi). Sehingga tingkat risiko saat ini kemungkinan pernah terjadi dan bila terjadi tingkat keparahannya tinggi.

n) Crew sakit

Ganguan kesehatan crew terjadi karena cuaca dingin, kelelahan, diet berlebihan, stress. Potensi atau dampak risiko yang dihadapi adalah crew tidak dapat melaksanakan tugasnya dengan baik sehingga kinerjanya terganggu, pengeluuaran biaya untuk pengobatan crew.

Tingkat Risiko saat ini berdasarkan tabel AS/NZS 4360:1999, tingkat kemungkinan berada di Level B (sering terjadi), tingkat akibatnya berada di level 3 (sedang). Sehingga tingkat risiko saat ini kemungkinan sering terjadi dan bila terjadi maka tingkat keparahannya sedang.

o) Crew tergelincir di tangga monyet

Crew tergelincir di tangga monyet terjadi karena ombak yang besar serta tangga yang licin dan basah terkena air laut. Potensi atau dampak risiko yang akan dihadapi adalah cidera ringan sampai cidera berat, pengeluuaran biaya untuk pengobatan crew yang cidera.

Tingkat Risiko saat ini berdasarkan tabel AS/NZS 4360:1999, tingkat kemungkinan berada di Level D (kecil kemungkinan terjadi), tingkat akibatnya berada di level 4 (tinggi). Sehingga tingkat risiko saat ini kemungkinan jarang terjadi dan bila terjadi maka konsekuensinya tinggi.

Berdasarkan data tersebut diatas, maka dapat dilihat bahwa hampir semua kegiatan di atas kapal dapat menyebabkan resiko yang tinggi. Beberapa penyebab kecelakaan diatas kapal sebagai berikut:

1. Standar Operasional Prosedur diatas kapal mengenai prosedur pelaksanaan dinas jaga tidak dilakukan sebagaimana mestinya

2. oil discharge monitori (odm) dan oily water separator (ows) tidak dioperasikan dengan baik
3. Latihan darurat di atas kapal jarang dilakukan

4. Crew kapal belum memahami pentingnya menggunakan PPE

5. Tidak ada staff darat yang dapat ditunjuk sebagai penanggung jawab kegiatan kapal

6. Nahkoda tidak dapat bertanggung jawab terhadap anak buah kapalnya.

Dari penyebab tersebut diatas, maka peneliti memberikan alternatif pemecahan masalah yaitu:

1. Pemberian pemahaman prosedur navigasi serta pemberian pelatihan secara berkala yang dilakukan oleh PT. Samudera Energi Tangguh tersebut sesuai dengan ISM - Code elemen 7 : pengembangan program untuk keperluan operasi-operasi di atas kapal, sehingga dengan penerapan ISM Code,

2. Penggunaan alat oil discharge monitori (odm) dan oily water separator (ows) di Kapal MT. Sinar Mataram pada PT Samudera Energi Tangguh tersebut sesuai dengan ISM - Code elemen 10 : Pemeliharaan kapal dan perlengkapannya, sehingga dengan penerapan ISM Code,

3. Latihan tanggap darurat di Kapal MT. Sinar Mataram pada PT. Samudera Energi Tangguh tersebut sesuai dengan ISM - Code elemen 8 : Kesiapan terhadap keadaan darurat, sehingga dengan penerapan ISM Code,

4. Kebijakan mengunakan PPE yang lengkap sesuai prosedur di Kapal MT. Sinar Mataram pada PT Samudera Energi Tangguh tersebut sesuai dengan ISM - Code elemen 2 : kebijakan mengenai keselamatan dan perlindungan lingkungan, sehingga dengan penerapan ISM Code,

5. Penunjukan seorang DPA (Designated Person Ashore) untuk kapal MT. Sinar Mataram pada PT. Samudera Energi Tangguh dimana kebijakan tersebut terdapat pada ISM - Code elemen 4 : Orang yang ditunjuk sebagai koordinator/penghubung antara pimpinan perusahaan dan kapal (DPADesignated Person Ashore), sehingga semua kegiatan yang berhubungan dengan keselamatan kapal dapat di pantau dan di control.

6. Pemberian tanggung jawab dan wewenang penuh kepada nahkoda untuk semua tahapan pengoperasian di laut, di pelabuhan maupun di darat, hal tersebut sesuai dengan ISM Code elemen : 5 Tanggung Jawab dan Wewenang Nahkoda / master.

Melihat dari alternatif yang telah dijabarkan, peneliti memberikan beberapa 
pertimbangan berupa keuntungan dan kerugian diantaranya sebagai berikut:

1. Pemberian pemahaman prosedur navigasi serta pemberian pelatihan secara berkala yang dilakukan oleh PT. Samudera Energi Tangguh

Keuntungan :

Berdasarkan analisis manajemen yang telah diuraikan, penerapan alternative ini dapat menurunkan risiko kecelaakaan sekitar $30 \%$ dari tahun sebelumnya.

Kerugian :

Perusahaan harus menyediakan biaya tambahan untuk meyelenggarakan pelatihan kepada mualim yang akan bergabung di atas kapal.

2. Penggunaan alat oil discharge monitori (odm) dan oily water separator (ows) di Kapal MT. Sinar Mataram

Keuntungan :

Alat ini mampu merekam minyak yang keluar dalam liter / mill laut sampai $15 \mathrm{ppm}$. Bila melebihi alarm berbunyi

Kerugian :

Jika terjadi kerusakan pada oil discharge monitori (odm) harus menghentikannya pembuangan minyak dan harus dicatat dalam buku catatan minyak

3. Latihan tanggap darurat secara berkala di Kapal MT. Sinar Mataram

Keuntungan:

Untuk mencegah keadaan darurat serta melakukan tindakan darurat untuk mengurangi keparahan baik risiko keselamatan, kesehatan kerja maupun dampak lingkungan pada karyawan dan crew.

Kerugian:

Akan mengakibatkan kerusakan infrastruktur yang terjadi akibat kegagalan aktivitas (operasional, proses, peralatan proses), produk dan jasa perusahaan yang menimbulkan keadaan darurat.

4. Memberlakukan aturan penggunaan Alat Pelindung Diri (APD)

Keuntungan :

Mengurangi risiko akibat kecelakaan dan melindugi seluruh/sebagian tubuhnya pada

kecelakaan

Kerugian :

Tidak menjamin pemakainya bebas kecelakaan

5. Penunjukan seorang DPA (Designated Person Ashore) untuk kapal MT. Sinar Mataram

Keuntungan :

Semua kegiatan yang berhubungan dengan keselamatan kapal dapat di pantau dan di kontrol. Kerugian:
Semua kegiatan yang berhubungan dengan keselamatan kapal tidak dapat berjalan dengan baik , karena seorang DPA tidak melaksanakan tugasnya dengan baik dan tidak sesuai prosedur yang sudah ditetapkan.

6. Pemberian tanggung jawab dan wewenang penuh kepada nahkoda untuk semua tahapan pengoperasian di laut, di pelabuhan maupun di darat.

Keuntungan :

a. Nahkoda menjadi lebih paham mengenai kegiatan yang dilakukan oleh anak buahnya di atas kapal

b. Nahkoda dapat menangani resiko yang yang akan terjadi di atas kapal

Kerugian :

a. Nahkoda tidak dapat melakukan kegiatan bebas sesuai keinginannya

\section{KESIMPULAN}

Berdasarkan hasil penelitian serta hasil analisis yang telah dilakukan sebelumnya dapat disimpulkan sebagai berikut:

1. Risiko yang teridentifikasi dari kegiatan yang berlangsung selama berlayarnya kapal meliputi Kapal kandas, kapal menabrak dermaga, kapal menabrak kapal lain, kebakaran, ledakan, limbah buangan dari got kapal, muatan tumpah, Tersengat arus listrik saat penyambungan arus, crew jatuh ke laut, crew terjatuh dari tangga, tali lempar mengenai crew di dermaga, crew terlilit tali kapal, crew sakit, crew tergelincir di tangga monyet

2. PT. Samudera Energi Tangguh telah menerapkan ISM Code dengan melaksanakan beberapa elemen ISM Code untuk menguragi angka kecelakaan diatas kapal, yaitu elemen 2 (dua) kebijakan mengenai keselamatan dan perlindungan lingkungan, elemen 4 (empat) Orang yang ditunjuk sebagai koordinator/penghubung antara pimpinan perusahaan dan kapal (DPA-Designated Person Ashore), elemen 5 (lima) Tanggung jawab dan wewenang Nakhoda / Master, elemen 7 (tujuh) pengembangan program untuk keperluan operasi-operasi kapal, elemen 8 (delapan) kesiapan terhadap keadaan darurat.

Berdasarkan penelitian dan pembahasan yang telah peneliti lakukan, peneliti memberikan beberapa saran sebagai masukan bagi perusahaan:

1. Nahkoda harus memberlakukan SOP (Standar Operasional Prosedur) kepada crew kapal dengan tegas, seperti penggunaan PPE (Personal Protective Equipment), latihan 
darurat, pengawasan pembuangan minyak dengan oil discharge monitori (odm) dan oily water separator (ows)

2. Nahkoda Kapal MT. Sinar Mataram harus menegaskan kembali kepada semua crew agar menggunakan PPE (Personal Protective Equipment) atau APD (Alat Pelindung Diri) yang lengkap sesuai prosedur untuk mengurangi risiko cidera dan melakukan komunikasi efektif dan berkelanjutin antara pihak kapal dengan pihak darat PT. Samudera Energi Tangguh melalui DPA (Designated Person Ashore) untuk mengevaluasi kebijakan manajemen keselamatan yang telah dilaksanakan.

3. Dilihat dari pengendalian risiko, penerapan ISM - Code di PT. Samudera Energi Tangguh sudah baik sehingga harus tetap di pertahankan atau lebih di tingkatkan. Dan agar temuan Noncomformity terutama yang major harus di tindak lanjuti / diselesaikan segera supaya kapal yang dioperasikan memenuhi ketentuan / peraturan yang berlaku

\section{DAFTAR PUSTAKA}

[1] Afrizal. (2014). Metode Penelitian Kualitatif : Sebuah Upaya Mendukung Penggunaan Penelitian Kualitatif dalam Berbagai Disiplin Ilmu. Jakarta: PT Rajagrafindo Persada.

[2] Australian/ New Zealand Standard. 2004. Australian Standad/New Zealand Standar 4360:2004"Risk Management"

[3] Djohannputro, Bramantyo. (2004). Manajmen Risiko Korporat Terintegrasi Memastikan Keamanan dan Kelanggengan Perusahaan Anda. Jakarta: PPM

[4] Gunawan, Herry. (2014). Pengantar Transportasi dan Logistik. Jakarta: PT Rajagrafindo Persada.

[5] Hasibuan, Malayu. (2011). Manajemen: Dasar, Pengertian, dan Masalah. Jakarta: PT Aksara.

[6] Handoko, T. Hani Handoko. (2003). Manajemen . Edisi 2 . Penerbit BPFE Yogyakarta, Yogyakarta .

[7] Keputusan Direktur Jenderal Perhubungan Laut Nomor : PY-67/1/7-96 tentang Pemberian Wewenang Kepada BKI Untuk Melaksanakan Verifikasi Manajemen Keselamatan Kapal Pada Kapal-Kapal Berbendera Indonesia

[8] Kodranus, Danggur. (2012) Keselamatan Kesehatan Kerja Membangun SDM Perkerja yang Sehat, Produktif dan Kompetitif. Jakarta : Bangka Adinatha Mulia
[9] Mukhtar. (2013). Metode Penelitian Deskriftif Kualitatif. Jakarta : GP Press Group

[10] Santoso, G. (2004). Manajemen Keselamatan Dan Kesehatan Kerja. Jakarta: Penerbit PP.

[11] Sihombing, Sarinah, dan Muljadi ( 2013). Pengantar Manajemen. Jakarta: Mitra Wacana Medika

[12] Suma'mur. 2009. Hiegiene Perusahaan dan Keselamatan Kerja. Jakarta : CV Sagung Seto.

[13] Suyono. (2005). Shipping Pengangkutan Intermodal Ekspor Impor Melalui laut. Jakarta : PPM

[14] Sugiyono. (2009). Metode Penelitian Kuantitatif, Kualitatif dan R\&D. Bandung : Alfabeta

[15] Sutabri, Tata. (2012). Analisis Sistem Informasi. Yogyakarta : Andi

[16] Peraturan Menteri Perhubungan Nomor 45 Tahun 2012 tentang Manajemen Keselamatan Kapal

[17] Internet

[18] https://www.researchgate.net/publication/31 8866689_Analisis_Risiko_Kegiatan_Bongka r_Muat_Sebagai_Komponen_Dwelling_Tim e_Di_Pelabuhan (diakses tanggal 26 Januari 2019 Pukul 17:03 WIB)

[19] http://www.maritimeworld.web.id/2011/08/ prosedur-keadaan-darurat-materi-

darurat.html (Diakses tanggal 14 Februari 2019 Pukul 13:39 WIB)

[20] http://www.portonews.com/2019/oil-andchemical-spill/minyak-tumpah-di-belmontpoint/ (Diakses tanggal 13 Maret 2019 Pukul 15:35 WIB)

[21] http://mukhtardaud.blogspot.com/2011/08/fr amework-risk-management-australia.html (Diakses tanggal 17 Maret 2019 Pukul 21:10 WIB)

[22] https://ikhrar.wordpress.com/tag/apakahpemberlakuan-ism-code-akan-menjaminkeselamatan-jelaskan/ (Diakses tanggal 21 Maret 2019 Pukul 06:58 WIB)

[23] http://gustinaajeng.blogspot.com/2014/11/tu gas-blog-1.html (Diakses tanggal 26 Maret 2019 Pukul 10:23 WIB)

[24] http://www.portonews.com/2017/oil-andchemical-spill/indonesia-darurat-tumpahanminyak/ (Diakses tanggal 26 Maret 2019 Pukul 10:29 WIB)

[25] https://shjamant.wordpress.com/2014/06/09/ alarm-keselamatan-dan-cara-penyelamatandi-laut/ (Diakses tanggal 26 Maret 2019 Pukul 10:47 WIB) 
[26] https://www.djkn.kemenkeu.go.id/2013/arti $\mathrm{kel} /$ penerapan-manajemen-risiko-berinisiatifmenjadi-kreatif-sekaligus-inovatif (diakses tanggal 26 Maret 2019 Pukul 10:06 WIB)

[27] http://www.hairulachsan.com/2016/07/progr am-drill-dan-latihan-di-kapal.html (Diakses tanggal 02 April 2019 pukul 10:01 WIB)

[28] http://www.hairulachsan.com/2016/07/progr am-drill-dan-latihan-di-kapal.html (Diakses tanggal 05 April 2018 pukul 09:01 WIB) 